\title{
KEEFEKTIFAN PENDEKATAN REALISTIC MATHEMATICS EDUCATION DENGAN METODE DRIL TERHADAP HASIL BELAJAR MATEMATIKA SISWA KELAS III SD
}

\author{
Widodo Hadi Pratomo'); Soegeng Ysh ${ }^{2)}$; Intan Rahmawati ${ }^{3)}$ \\ Universitas PGRI Semarang \\ wido2jr@gmail.com
}

\begin{abstract}
The problem of this research is does the approach of realistic mathematics education with drill method is effective against mathematics learning outcomes third grade students of SDN Peterongan Semarang in the academic year 2016/2017? Based on the problems posed hypotheses as follows: realistic approach to mathematics education with drill method is effective against mathematics learning outcomes third grade students of SDN Peterongan Semarang academic year 2016/2017. The goals to be achieved in this study was to determine the effectiveness of the approach is realistic mathematics education methods drill on learning outcomes third grade students of elementary mathematics $N$ Peterongan Semarang in the school year 2016/ 2017. this type of research is quantitative. The population in this study were students of class III Elementary School Peterongan Semarang. The sample class III A control group of 32 students and class III B as an experimental group of 32 students. Experimental research design using a true experimental design, shape chosen is posttest only control group desaign. Data collection tool used is multiple choice test. The results of the t test analyzes is one side (right side) obtained t arithmetic >t table is 5.461>1.670, then Ho is rejected. Thus, the realistic approach to mathematics education with drill methods have the significant difference to student learning outcomes experimental class control class. Acquisition of individual mastery learning in the experimental group that is $100 \%$ and the average value of 84.218. A control group with a percentage of $87.5 \%$ and the average value of 73.718 . So it can be concluded that the approach of realistic mathematics education with drill method is effective against mathematics learning outcomes third grade students of SDN Peterongan Semarang.
\end{abstract}

Keywords: realistic mathematics education, drill method, outcomes, mathematics

\section{PENDAHULUAN}

Pendidikan memiliki peranan penting dalam kehidupan suatu bangsa guna menjamin perkembangan dan kelangsungan bangsa yang bersangkutan. Menurut Undangundang Republik Indonesia Nomor 20 Tahun 2003 tentang Sistem Pendidikan Nasional (Soegeng, 2007: 9). Pendidikan adalah usaha sadar dan terencana untuk mewujudkan suatu belajar dan proses pembelajaran agar peserta didik aktif mengembangkan potensi dirinya untuk memiliki kekuatan spriritual keagamaan, pengendalian diri, kepribadian, kecerdasan, akhlak mulia serta ketrampilan yang diperlukan dirinya, masyarakat, bangsa dan negara.
Seiring perkembangan ilmu pengetahuan dan teknologi menuntut peningkatan mutu pendidikan yang dapat dilakukan dengan perbaikan-perbaikan, perubahan-perubahan dan pembaharuan terhadap aspek-aspek yang mempengaruhi keberhasilan pendidikan meliputi kurikulum, sarana dan prasarana, guru, siswa, dan metode belajar mengajar.

Dalam proses pendidikan di sekolah, kegiatan belajar mengajar merupakan salah satu kegiatan penting. Guru merupakan salah satu faktor penentu keberhasilan kegiatan belajar mengajar (Fathurrohman, 2012, 13). Berbagai usaha telah dilakukan oleh guru SD dengan harapan materi pelajaran yang disampaikan oleh guru tersebut dapat 
dipahami dan dikuasai oleh anak didiknya (Susanto, 2013).

Kurikulum merupakan salah satu unsur yang tidak dapat dipisahkan dari pendidikan. Kurikulum merupakan landasan pendidikan yang akan diterapkan pada satuan pendidikan tertentu, baik itu jenjang pendidikan Sekolah Dasar (SD), Sekolah Menengah Pertama (SMP), maupun Sekolah Menengah Atas (SMA). Kurikulum juga menjadi acuan guru untuk menerapkan model, metode, ataupun media yang akan digunakan dalam pembelajaran di kelas. Kurikulum menjadi sangat penting keberadaannya dalam sistem pembelajaran di Indonesia. Kurikulum dapat memberikan kontribusi yang signifikan untuk pendidikan yaitu untuk mewujudkan proses berkembangnya kualitas potensi peserta didik. Berhasil atau tidaknya kurikulum dapat dilihat dengan bagaimana hasil siswa dalam proses pembelajaran (Slameto, 2010).

Khusus bagi guru sekolah dasar, harus menguasai dan mampu mengajarkan berbagai mata pelajaran yang termuat dalam kurikulum yang digunakan saat ini, yaitu Kurikulum Tingkat Satuan Pendidikan (KTSP). Salah satu mata pelajaran yang termuat dalam KTSP yaitu Matematika. Matematika merupakan salah satu mata pelajaran yang memiliki peran penting dalam mencapai tujuan pendidikan, karena Matematika merupakan mata pelajaran yang membekali siswa untuk berpikir logis, analitis, sistematis, kritis dan kreatif (Fajariyah, 2008).

Mata pelajaran matematika merupakan mata pelajaran yang sarat muatan kognitif dan afektifnya. Pada ranah kognitif, mata pelajaran tersebut bertujuan mengembangkan kemampuan siswa dalam menyelesaikan masalah, dan pada ranah afektif mata pelajaran matematika mengembangkan ketelitian dan kesabaran siswa dalam menyelesaikan masalah yang berhubungan dengan angka-angka.

Dalam mengajar, guru harus pandai menggunakan pendekatan secara arif dan bijaksana, bukan sembarangan yang bisa merugikan anak didik. Pandangan guru terhadap anak didik akan menentukan sikap dan perbuatan. Setiap guru tidak selalu mempunyai pandangan yang sama dalam menilai anak didik. Hal ini akan mempengaruhi pendekatan yang diambilnya dalam pembelajaran. Guru yang mempunyai pandangan sempit, biasanya akan menggunakan pendekatan yang biasa dipakainya sejak ia pertama kali mengajar, atau biasanya ia akan menirukan gurunya dahulu ketika mengajar. Hal itu akan membuat guru tidak profesional dalam melakukan pembelajaran dan hasilnya tidak akan memuaskan.

Salah satu contoh pendekatan pembelajaran dalam matematika yaitu realistic mathematics education atau sering disingkat RME (Wijaya, 2012; Prabawanto, 2006: 34). RME merupakan suatu pendekatan yang bertujuan memotivasi siswa untuk memahami konsep matematika, dengan cara mengaitkan konsep tersebut dengan permasalahan dalam kehidupan sehari-hari. Pendekatan pembelajaran RME merupakan salah satu pendekatan pembelajaran yang sesuai dengan jenis pengetahuan matematika yang kontekstual. Oleh karena itu, permasalahan yang digunakan dalam pembelajaran RME harus memiliki keterkaitan dengan dunia nyata yang mudah dipahami dan dibayangkan siswa. Sesuatu yang dibayangkan siswa tersebut akan menjadi titik tolak atau titik awal dalam pemahaman konsep matematika.

Proses pembelajaran menggunakan metode mempunyai kedudukan yang sangat 
penting dalam upaya pencapaian tujuan, karena metode merupakan suatu cara atau jalan yang ditempuh yang sesuai dan serasi untuk menyajikan suatu hal, sehingga akan tercapai suatu tujuan pembelajaran yang efektif dan efisien. Ada berbagai macam metode pembelajaran, yaitu metode ceramah, metode demonstrasi, metode diskusi, metode drill dan lain-lain (Suwangsih, 2006; Sugiato, 2009). Metode drill adalah metode dalam pengajaran dengan melatih peserta didik terhadap bahan yang sudah diajarkan/ diberikan agar memiliki ketangkasan atau ketrampilan dari apa yang telah dipelajari. Tujuan dari penggunaan metode drill salah satunya untuk mengembangkan kecakapan intelek, seperti mengalikan, membagikan, menjumlah, tanda baca, dan lain-lain (Sutarmiyati, 2016).

Hasil belajar adalah kemapuankemampuan yang dimiliki siswa setelah ia menerima pengalaman belajarnya (Sudjana, 2013: 22). Menurut Dimyati dan Mudjiono (2009: 250) "hasil belajar merupakan hal yang dapat dipandang dari dua sisi yaitu peserta didik dan dari sisi guru". Dalam kegiatan pembelajaran semua pihak-pihak yang terkait pasti menginginkan suatu hasil belajar yang baik. Hasil belajar yang baik didapatkan melalui kerjasama yang baik pula antara siswa dan guru.

Berdasarkan hasil observasi dan wawancara kepada guru kelas III B ibu Sri Hartini, S.Pd., M.Pd. pada tanggal 06 September 2016 di SDN Peterongan, menjelaskan bahwa guru mengaku masih belum menguasai sepenuhnya pendekatan, metode, dan model-model dalam pembelajaran. Ibu Sri Hartini mengaku belum pernah menerapkan pendekatan RME dengan metode drill dalam pembelajaran matematika. Dalam kegiatan pembelajaran menunjukkan proses penyampaian materi secara umum atau model pembelajaran yang kurang bervariasi sehingga proses pembelajaran kurang maksimal dalam mencapai tujuan pembelajaran yang diharapkan. Dalam hal ini guru masih banyak menemui kendala mengenai keaktifan dan keberanian siswa dalam mengemukakan pendapat. Bahkan beberapa siswa malah ramai sendiri mengobrol dengan teman jalan kesana-kemari saat proses pembelajaran berlangsung. Akhirnya pada hasil belajar Ulangan Tengah Semester (UTS) mata pelajaran matematika sebagian siswa belum memenuhi Kriteria Ketuntasan Minimal (KKM) sebesar 65. Ratarata nilai UTS matematika kelas III B yaitu 69,63 dari 32 siswa. Hasil observasi dengan ibu Suwarsih S.Pd. sebagai guru kelas III A juga mengatakan demikian seperti yang dijelaskan oleh ibu Sri Hartini. Rata-rata nilai UTS matematika kelas III A yaitu 68.28 dari 32 siswa. Sebagian siswa nilainya masih belum memenuhi KKM.

Guru menjelaskan alasan pencapaian nilai UTS siswa yang rata-rata masih di bawah KKM tersebut. Menurut ibu Sri Hartini pencapaian tersebut dikarenakan siswa belum terbiasa dengan soal-soal yang sebelumnya belum siswa peroleh waktu pembelajaran sehari-hari. Soal UTS dibuat oleh tim perancang dari kecamatan bukan dari sekolah masing-masing, jadi siswa masih tabuh dengan bentuk soal-soal yang tidak biasanya siswa jumpai pada saat kegiatan belajar mengajar berlangsung.

Berdasarkan latar belakang di atas, Peneliti ingin mengetahui keefektifan pendekatan realistic mathematics education dengan metode drill apabila diterapkan di dalam pembelajaran khususnya kelas III mata pelajaran matematika dengan judul "Keefektifan Pendekatan Realistic 
Mathematics Education dengan Metode Drill terhadap Hasil Belajar Matematika Siswa Kelas III SDN Peterongan Semarang”.

\section{METODOLOGI}

Penelitian ini menggunakan pendekatan kuantitatif. Penelitian ini dilakukan di SDN Peterongan Semarang pada semester genap Tahun Pelajaran 2016/ 2017. Dalam penelitian ini Peneliti menggunakan desain eksperimen sungguhan dengan jenis posttestonly control design dengan gambar sebagai berikut (Arikunto, 2010, 55):

Tabel 1. Desain Penelitian

\begin{tabular}{|c|c|c|}
\hline Kelompok & Perlakuan & Tes akhir \\
\hline Eksperimen & $\mathrm{P}$ & $\mathrm{O}_{1}$ \\
\hline Kontrol & $\mathrm{X}$ & $\mathrm{O}_{2}$ \\
\hline
\end{tabular}

Dalam desain ini terdapat dua kelompok, kelompok pertama eksperimen kelas III B diberi perlakuan pendekatan RME dengan metode drill (P) dan kelompok kedua kontrol kelas III A diberikan perlakuan biasa atau konvensional (X). Pengaruh adanya perlakuan (treatment) adalah $\left(\mathrm{O}_{1}: \mathrm{O}_{2}\right)$. Dalam penelitian ini Peneliti mengajarkan materi keliling dan luas persegi dan persegi panjang pada mata pelajaran matematika kelas III SD. Penelitian ini menggunakan 2 variabel yaitu:

1. Variabel Bebas (X)

Penelitian ini yang menjadi variabel bebas adalah pendekatan RME dengan metode drill.

2. Variabel Terikat (Y)

Variabel terikat dalam penelitian ini adalah hasil belajar matematika siswa kelas III SDN Peterongan Semarang.

Analisis data dilakukan untuk menguji hipotesis dalam rangka penarikan kesimpulan mencapai tujuan penelitian. Analisis data merupakan suatu cara untuk mengelola data hasil penelitian guna memperoleh suatu kesimpulan. Uji normalitas adalah pengujian terhadap normal tidaknya sebaran data yang dianalisis. Uji normalitas yang digunakan adalah uji Liliefors. Sedangkan uji hipotesis akan menggunakan uji $\mathrm{t}$ untuk jenis uji hipotesis dua pihak (Sugiyono, 2014).

Berdasarkan pengujian terhadap kriteria keefektifan ada 3 aspek yaitu: (1) terdapat pengaruh dari pendekatan RME dengan metode drill. Mengukur pengaruh pendekatan RME dengan metode drill terhadap hasil belajar dengan melihat rata-rata posttest kelas eksperimen $\left(\overline{\mathrm{X}}_{1}\right)$ dan kelas kontrol $\left(\overline{\mathrm{X}}_{2}\right)$. Kriteria: Jika $\bar{X}_{1} \geq \bar{X}_{2}$ maka, tidak ada pengaruh pendekatan RME dengan metode drill terhadap hasil belajar matematika siswa kelas III SDN Peterongan Semarang. Jika $\bar{X}_{1}>\bar{X}_{2}$ maka, ada pengaruh pendekatan RME dengan metode drill terhadap hasil belajar matematika siswa kelas III SDN Peterongan Semarang; (2) terdapat perbedaan yang signifikan dari pendekatan RME dengan metode drill. Mengukur perbedaan signifikan menggunakan uji $t$; dan (3) hasil belajar matematika siswa mencapai kriteria ketuntasan minimal individu. Jadi kriteria ketuntasan individu 65. $\mathrm{N}$ merupakan hasil belajar matematika dengan kriteria: Jika $\mathrm{N} \geq$ 65 maka, siswa dinyatakan tuntas. Jika $\mathrm{N}<65$ maka, siswa dinyatakan tidak tuntas.

Berdasarkan ketentuan Kurikulum Tingkat Satuan Pendidikan (KTSP) penentuan ketuntasan belajar ditentukan sendiri oleh masing-masing sekolah yang dikenal dengan istilah kriteria ketuntasan minimal, dengan berpedoman pada tiga pertimbangan, yaitu: kemampuan setiap peserta didik, sarana prasarana setiap sekolah dan daya dukung setiap sekolah. Maka dalam penelitian ini, sesuai dengan KKM mata pelajaran 
matematika, maka ketuntasan individual adalah 65. Setiap siswa dikatakan tuntas belajarnya jika proporsi jawaban benar siswa $\geq 65$.

\section{HASIL DAN PEMBAHASAN}

Perhitungan yang digunakan untuk mengetahui normalitas sampel dari populasi dilakukan dengan menggunakan uji Lilliefors, pada taraf signifikansi 5\% n1= 32 dan $\mathrm{n} 2=32$, baik untuk kelompok eksperimen dan kelompok kontrol sehingga populasi berdistribusi normal. Uji normalitas menggunakan hasil nilai posttest matematika materi keliling dan luas persegi dan persegi panjang. Uji normalitas hasil posttest kelas eksperimen untuk $\mathrm{n}=32$ dan taraf nyata $\alpha=$ $5 \%$, dengan uji Liliefors diperoleh $\mathrm{L}_{0}=0,116$ dan $\mathrm{L}_{\text {tabel }}=0,157$. Dari data tersebut dapat disimpulkan bahwa $\mathrm{L}_{\mathrm{o}}<\mathrm{L}_{\text {tabel }}$ atau 0,116 < 0,157, sehingga $\mathrm{H}_{\mathrm{o}}$ diterima.

Jadi sampel berasal dari populasi yang berdistribusi normal. Uji normalitas hasil nilai posttest kelas kontrol untuk $\mathrm{n}=32$ dan taraf nyata $\alpha=5 \%$, dengan uji Liliefors diperoleh $\mathrm{L}_{\mathrm{o}}=0,070$ dan $\mathrm{L}_{\text {tabel }}=0,157$. Dari data tersebut dapat disimpulkan bahwa $\mathrm{L}_{0}<\mathrm{L}_{\text {tabel }}$ atau 0,070 $<157$, sehingga $H_{o}$ diterima. Jadi sampel berasal dari populasi yang berdistribusi normal.

Berdasarkan hasil penelitian menunjukkan bahwa pembelajaran pada kelas eksperimen lebih baik dari pada kelas kontrol. Hal ini dapat dilihat dari hasil rata-rata kelas eksperimen yaitu 84.218 dengan persentase ketuntasan $100 \%$, semua siswa dinyatakan tuntas. Sedangkan untuk rata-rata kelas kontrol yaitu 73.718 dengan persentasi ketuntasan $87.5 \%$. Terdapat 4 siswa yang tidak tuntas nilainya di bawah KKM 65 .

Uji $t$ menyatakan bahwa rata-rata kelompok eksperimen $\bar{X}=84,218$ dan rata-rata kelompok kontrol $\bar{X}=73.718$ dengan $\mathrm{n}_{1}=32$ $\mathrm{n}_{2}=32$ diperoleh $\mathrm{t}_{\text {hitung }}=5.461$ dengan $\alpha=5 \%$ dan $\mathrm{dk}=32+32-2=62$ diperoleh $\mathrm{t}_{\text {tabel }}=1.67$. $t_{\text {hitung }}>t_{\text {tabel }}$ maka $\mathrm{H}_{\mathrm{o}}$ ditolak $\mathrm{H}_{\mathrm{a}}$ diterima, sehingga ada pengaruh pendekatan realistic mathematics education dengan metode drill terhadap hasil belajar matematika siswa kelas III SDN Peterongan Semarang. Hal ini menunjukkan bahwa penggunaan pendekatan realistic mathematics education dengan metode drill lebih baik dibandingkan dengan hanya menggunakan model konvensional, artinya hasil belajar matematika siswa pada materi keliling dan luas persegi dan persegi panjang dari siswa kelas eksperimen lebih baik daripada hasil belajar siswa kelas kontrol.

Pembelajaran pada kelas kontrol yang menggunakan model konvensional, siswa mengikuti pembelajaran sudah cukup baik meskipun dalam proses pembelajarannya monoton dan kurang menarik. Hal ini membuat siswa sedikit bosan dan terkadang siswa ramai sendiri. Pada pembelajaran di kelas eksperimen yang menggunakan pendekatan RME dengan metode drill, siswa terlibat dalam kegiatan berpikir, menulis, berbicara, dan bertindak sehingga siswa menjadi lebih aktif. Dengan metode drill siswa menjadi lebih terbiasa dengan menghadapi soal-soal latihan. Siswa akan lebih terampil dan siap dalam menghadapi sesuatu persoalan matematika yang didapatinya. Disamping dapat berpikir konkrit siswa juga akan mendapatkan rasa percaya diri dan berani dalam menghadapi pertanyaan-pertanyaan. Hal ini sesuai dengan pendapat Bruner yang mengatakan bahwa proses belajar akan berjalan dengan baik dan kreatif jika guru memberikan kesempatan kepada siswa untuk menemukan suatu 
konsep, teori, aturan, atau pemahaman melalui contoh-contoh yang siswa jumpai.

Hasil belajar siswa kelas eksperimen yang menggunakan pendekatan RME dengan metode drill lebih baik dan lebih efektif daripada siswa kelas kontrol karena siswa lebih terampil dan siap ketika menemui permasalahan yang sebelumnya sudah terlatih. Hal itu dibuktikan dengan perbedan nilai posttest hasil belajar antara kelas eksperimen dan kelas kontrol.

\section{SIMPULAN}

Berdasarkan hasil penelitian yang telah dilaksanakan dapat disimpulkan bahwa penggunaan pendekatan RME dengan metode drill efektif terhadap hasil belajar matematika siswa kelas III SDN Peterongan Semarang.
Hal ini sesuai dengan kriteria keefektifan yang terdapat dalam aspek, bahwa: (1) nilai rata-rata kelas eksperimen lebih besar dari kelas kontrol $\left(\bar{X}_{1}>\bar{X}_{2}\right)$. Terbukti bahwa nilai rata-rata kelas eksperimen 84.218 dan nilai rata-rata kelas kontrol 73.718 , artinya $\bar{X}_{1}>$ $\bar{X}_{2}$; (2) terdapat pengaruh pendekatan RME dengan metode drill, hal ini berdasarkan analisis data hasil penelitian dengan menggunakan uji-t diperoleh $\mathrm{t}_{\text {hitung }}=5.461$ dan $t_{\text {tabel }}=1.67$ sehingga $t_{\text {hitung }}>t_{\text {tabel }}$ maka $H_{o}$ ditolak $\mathrm{H}_{\mathrm{a}}$ diterima; dan (3) hasil belajar matematika siswa mencapai kriteria ketuntasan minimal individu. Terlihat dari persentase ketuntasan hasil belajar siswa kelas eksperimen yang menggunakan pendekatan RME dengan metode drill yaitu sebanyak 32 peserta didik atau $100 \%$ telah mencapai kriteria ketuntasan minimal individu.

\section{DAFTAR PUSTAKA}

Arikunto, Suharsimi. 2010. Prosedur Penelitian Suatu Pendekatan Praktik. Jakarta: Rineka Cipta.

Dimyati dan Mudjiono. 2009. Belajar dan Pembelajaran. Jakarta: Rineka Cipta.

Fajariyah, Nur dan Defi Triatnawati. 2008. Cerdas Berhitung Matematika 3 untuk SD/ MI Kelas III.Jakarta: CV. Grahadi.

Fathurrohman, Muhammad dan Sulistyorini. 2012. Belajar dan Pembelajaran. Yogyakarta: Teras.

Prabawanto, Sufyani dan Mujono. 2006. Model Pembelajaran Matematika. Bandung: UPI Press.

Slameto. 2010. Belajar Dan Faktor-Faktor Yang Mempengaruhi. Jakarta: Rineka Cipta.

Soegeng, A. Y. 2007. Filsafat Pendidikan. Semarang: IKIP PGRI Press.

Sudjana, Nana. 2013. Penilaian Hasil Proses Belajar Mengajar. Bandung: Remaja Rosdakarya. 
Sugiato, Yusak. 2009. "Efektivitas Pendekatan Matematika Realistik dalam Meningkatkan Prestasi Belajar Matematika Ditinjau dari Kemampuan Awal Siswa SMK”.http://eprints.uns.ac.id/8924/1/80452107200907021.pdf_(diunduh 15 Juli 2016).

Sugiyono. 2014. Metode Penelitian Kuantitatif, Kualitatif dan R\&D. Bandung: Alfabeta.

Susanto, Ahmad. 2013. Teori Belajar dan Pembelajaran di SD. Jakarta: Kencana.

Sutarmiyati. 2016. "Penggunaan Metode Drill pada Materi Ajar Penjumlahan Bilangan Pecahan”. i-rpp.com/index.php/jpp/article/download/360/360 (diunduh 15 Juli 2016).

Suwangsih, Erna dan Tiurlina. 2006. Model Pembelelajaran Matematika. Bandung: UPI Press.

Wijaya, Ariyadi. 2012. Pendidikan Matematika Realistik, Suatu Alternatif Pendekatan Pembelajaran Matematika. Yogyakarta : Graha Ilmu. 